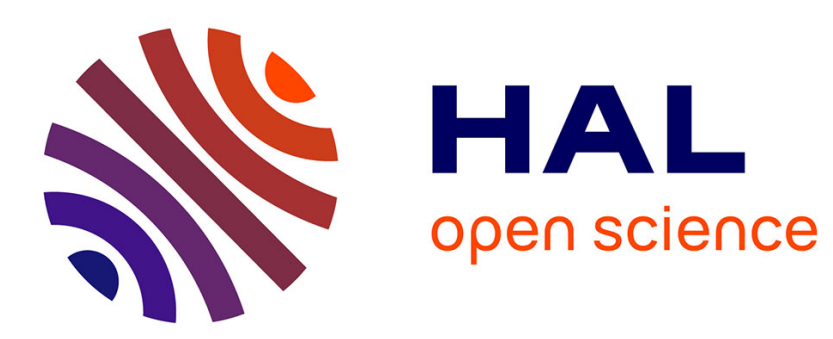

\title{
Innovation policies and values of females managers from the Gulf: a qualitative study
}

\author{
Arnaud Lacheret
}

\section{To cite this version:}

Arnaud Lacheret. Innovation policies and values of females managers from the Gulf: a qualitative study. Journal of Strategic Innovation and Sustainability, 2020, 15 (5), 10.33423/jsis.v15i5 . halshs03093610

\section{HAL Id: halshs-03093610 \\ https://shs.hal.science/halshs-03093610}

Submitted on 4 Jan 2021

HAL is a multi-disciplinary open access archive for the deposit and dissemination of scientific research documents, whether they are published or not. The documents may come from teaching and research institutions in France or abroad, or from public or private research centers.
L'archive ouverte pluridisciplinaire HAL, est destinée au dépôt et à la diffusion de documents scientifiques de niveau recherche, publiés ou non, émanant des établissements d'enseignement et de recherche français ou étrangers, des laboratoires publics ou privés. 


\title{
Innovation Policies and Values of Female Managers From The Gulf: A Qualitative Study
}

\author{
Arnaud Lacheret \\ Arabian Gulf University
}

\begin{abstract}
Promoting an innovative mindset is one of the main objectives of all the Governments and institutions of the Arabo-Persian Gulf. This paper introduces part of findings of a qualitative study on female managers from 3 countries of the GCC impacted by those reforms. The research leads to a new definition of modernity in the Arabian world, impulsed by the women and their dramatic contribution to the changing of the mindset of the region. This changing mindset driven by the new behaviour and attitudes of women is a key driver to promote innovation within the Gulf region more than all kind of new regulations to encourage it.
\end{abstract}

Keywords: Gulf countries, women empowerment, leadership, Islam, innovation policies

\section{INTRODUCTION}

The Gulf region, which used to be considered as a land of conservatism and oil dependent economy, has decided to launch large and wide policy reforms during the past years

The most visible parts of those reforms are obviously the various national strategic plans drafted and implemented in order to modernize those countries and allow them to achieve sustainability in a post oil era. Most of those plans rely on robust consulting analysis, conducted by the best specialists in the world. As an example, the most relevant plan, Saudi Vision 2030, has been prepared in collaboration with Mac Kinsey consultants. Such plan makes the best of lots of statistics encompassing both highly granular, and precise economic data and wide range surveys and draws from them a set of ambitious conclusions.

Among those conclusions, the empowerment of national females appears as a priority for all the Gulf countries. Measures and regulations have purposely been taken following the finalisation of the plan and the most spectacular changes have occurred in Saudi and have been promoted in the international press.

This momentum is rather unique in the world, especially in terms of speed of the political and social changes in the region.

Ignoring those national strong efforts, analyses and research papers recently published about the Gulf region do acknowledge neither the outcomes nor the successes achieved so far but rather stay over focused on religious and cultural issues. Most of western researchers observe change from afar or by doing short travels in those countries. They are therefore facing challenges to perceive the materiality of change, ending up arguing that the main issue is the rigid and conservative mindset that prevent and curb the pace of change. 
As a scholar and MBA program manager based in the Gulf since 2017 in a local university, it has been decided to launch a long range qualitative research on one of the most important and claimed stake of the future of the GCC countries: the empowerment of women.

The genesis of this research lies in the identification of a gap in the existing scientific papers between the global economic surveys and statistics used by the consultants assisting the local Governments in the implementation of the reforms, and the papers dealing with women in the Arabian world. The latter studies are mainly based on two very different methodologies: qualitative and quantitative research in management science and ethnologic and anthropologic science in "feminist" studies. Both of them, despite their huge differences are mainly focused on religious aspects, claiming that they are shaping the values of local GCC women.

During the first month embedded in this 100\% Arabian university, the first impressions and observations were quite different, and the strong impact of religion in people's behaviour has not been found out. On the contrary, although Islam is obviously very important in Arab lives, first conversations and exchanges with my students and colleagues lead to think that the previous studies were biased and too much religion oriented.

Due to the fact that many GCC national female managers were part of the MBA program and seemed ready to participate in a scientific study, it was decided to launch a mixed anthropologic and qualitative research based on interviews with an allegedly quasi inexistent population according to the existing studies: female managers of the Gulf. The main research problem was to try and check whether the religion oriented existing studies were relevant or outdated.

Shortly after the beginning of this research, it was found out that the picture was far more complicated than reported in the existing literature. The research's purpose had to be reoriented toward a wider goal, that of identifying values carried by female managers of the Gulf and how they contribute to the changing of mindset within their countries through their role of "micromodels" toward their relatives, colleagues, neighbourhood...

The present paper is just a part of the findings of the study conducted from 2017 to 2020 . In order to launch innovation driven policies as advised by the international consultants hired by them, Governments have actually to be aware of the way values and traditions are evolving through the role of those women micromodels. Doing differently would be to ignore that executive women are now fully part of the Gulf societies and are an integral part of the changing processes in the mindsets of the economic and social Gulf ecosystems.

\section{RESEARCH METHODOLOGY}

The qualitative research consisted in finding out the values carried by the female managers from the Gulf. The questionnaire was inspired by past research work based on a population whose characteristics were similar. Actually, Memoona Tariq and Jawad Syed had conducted a study on the same population of Muslim women having reached some managerial positions in Britain. Most of those women were coming from south Asia, which refers to the Indian and Pakistani regions. The object of the study was the difficulties faced by an intersectional public (female, foreigner, Muslim) in their career path (Tariq, Syed, 2017).

Our exploratory study targeting Arabian women from the Gulf borrowed a subset of the questions asked by those two sociologists and added some more cultural and religious items on the second part of the interview. The first part of the semi conducted interviews aimed to make women talk about themselves, their career paths, their achievements, their vision of companies and possible difficulties they have encountered in workplace or into their family to progress in their career paths. The most important things were, to borrow to the feminist sociologists, to make them speak of their "selves" by giving concrete examples in order to "start from the experience" through discussion on the perception of the self, expression of emotions presented as keys of understanding (De Vault, 1999). Elements of sociologic evidences have to be enriched by "elements of the daily experience", inspired by the methodology defined by Howard Becker to run a qualitative research (Becker, 2014). 
Thus, the most important part of the interviews was to make them start with elements linked to the professional life of those women, in order to make them describe some usual and familiar situations and define concepts they were supposed to master due to their professional position. This is why the first questions of the interviews are focusing on the way they have reached their current professional level, what they had to undertake to get there, obstacles they have faced, by focusing each time through the prism of gender that is pervasive during the recorded conversations.

We have borrowed a dramatically important point from the study of Tariq and Syed: the notion of leadership. This question arrives chronologically in the interviews just after the detailed description of the position held by the interviewees and is asked as follows: "What is your view and understanding of a leader in the context of work and organisations?" After the first interviews, we have sometimes added a reminder which was "So do you consider yourself as a leader?" in order to hear more about the selfidentification of the interviewee as a leader or not.

Amongst other things, this personal definition of the role of a leader lead us to focus on the theme of the managerial values. The notion of leader is actually related to the emerging values as well as the processes of mutual influence arising between the members of a group and his or their leaders and contribute to their performance, their motivation and their satisfaction (Forsyth, 1998). More recent visions of leadership define it like a relational dynamic that can be shared within a team (Avolio, Walumbwa, Weber, 2009). The interviewees, who are almost all at managerial positions, can therefore develop a definition of a leader that surely embodied cultural, traditional and religious considerations.

Once the interviewee has defined what she was calling leadership, most of times through concrete examples of experiences linked with her professional environment, the themes evoked can easily deal with issues in terms of management, internal or external promotion and even discrimination. Questions about leadership are above all questions about values and transmission: the way leadership is defined allows opening new doors on values and traditions tight to them.

During the interviews, it appeared that the way women conceived leadership was linked to the "neocharismatic" theory (Winkler, 2009). This leadership theory is tightly linked to the notion of change, innovation, transformation of the subordinates. The "charismatic" aspect can be found in the characteristics and behaviours of the leaders defined by the interviewees. For the supporters of this approach, the leader has to carry a vision in the sense that he has to transform the ones who follow this vision and give stronger meaning and purpose to the actions they undertake (Van Seters and Field, 1990).

The study is composed of 20-recorded interviews of 45 to 90 minutes each with female managers from the GCC region. The average age of the interviewees is 33 years old (from 21 to 49 years old), 9 are Saudi, 9 are from Bahrain and 2 from Kuwait. 2 of them are entrepreneurs, 15 of them are managers or executives in the private sector with more of 5 years of work experience, 1 is a manager in the public sector, 2 of them are undergraduate students. The interviews were conducted in English language, most of times in an office at the University but some of them have been recorded in other places. To check the reliability of the replies and avoid language and position bias (due to the interviewer's position as a male westerner and head of a postgraduate program), an assistant was in charge to have informal conversations in Arabic with them on the most sensitive aspects of the questionnaire to check if the discrepancies in their answers were very important before or after the recorded interviews (it has never been the case.)

In addition to this, we have conducted anthropological observations during multiple professional visits and informal discussions with colleagues, students and various actors of the region. Another source of research has been the organization of focus groups in collaboration with Professor Cedomir Nestorovic, specialist of Islamic marketing. We have been gathering small groups of students (35 years old of average age) and questioned them on different aspects of the family, professional and private life in the Gulf to have the better possible keys of understanding of the context of the research.

\section{LITERATURE REVIEW}

This outcome leads us to a definition that matches well with the ancient one of "transformational leader" (Burns, 1978, Bass, 1985) that was conceiving leadership as a tool of influence of the leaders on 
his subordinates by using specific and precise leverages. First, a transactional leverage, because the leader is supposed to use the couple "negotiation/discussion" with his subordinates to reach precise objectives while controlling and appraising their performances in intervening only in case of major issue. Secondly, we also found a transformational leverage in which the leader encourages his subordinates to "work in the sense of objectives transcending their individual interests. He proposes an attractive vision of the future, defines some difficult to reach objectives, questions traditions and beliefs and stimulates drafting of new perspectives. He considers everyone as an individual to be taken into consideration and offers his support" (Allard-Poesi, 2012). The transformational leadership is a core value of the "neo-charismatic" definition and drives a romantic and omnipotent conception of the leader (Avolio et al, 2009.)

Transformational and transactional approaches have been considered as very different notions for a while until research found out that those two concepts where far closer than they seemed (Judge, Piccolo, 2004).

In management science, lots of other approaches and interactions have been studied and especially the role of « followers » (Howell, Shamir, 2004) and the conditions of efficiency of a type of leadership or another one (House et al, 1997). However, regarding the content of the interviews, it appears obvious that the core of the definition of leadership according to the female manager in the Gulf region was its "neocharismatic" definition.

In the exploratory research we have conducted, we weren't seeking to find out the realities nor the ways professional relations were organized but rather to cast a light on the perceptions, the feelings of the interviewees, and the way they could verbalise, build a speech on leadership and derive a vision from it, as a frame inside which their values could flourish.

Following the question about leadership, the next part of the interview dealt with the difficulties faced at work and attached to gender. It was covered by two questions asked in slightly different ways so that the second question could complete the first one. The first one was: "To what extent has your gender has affected you in achieving senior managerial or leadership role in your organization. To what extent can it be a difficulty for you career?" and then "Did you ever feel being treated differently at work because of your gender?" Those questions aimed to push the interviewees in disclosing some anecdotes or situations during which they felt discriminated. Between those two questions was positioned another one investigating "culture" and "traditions of their country" and the way those items could have affected their career path. It was formulated as follows: "To what extent the cultural background of your country has affected you achieving senior managerial or leadership roles?"

This paper is not aiming to address the cultural issue and this question is anyway not included in the coding of the data in order to analyse the values through the managerial framework. However, the relation between the definition of leadership and potential discriminations faced as a woman appears very important to address in order to identify values carried by the women aiming to take a role of leader by avoiding eventual gender issues.

The women specific values are also addressed through two other questions coming later in the interviews. The first one investigates the definition of the main achievement in a woman's life. According to the characteristics of the women interviewed (managers, around 30 years old, most of times single), it permits to figure out the priorities they give to their life, and broader to woman's life.

Finally, this paper addressing values shared in the workplace is investigating the "specific values" that a woman can carry in her professional backyard. Asked at the end of the interviews, after the cultural and religious part, this question aims to confirm the assumptions upon which the woman emancipation in the Gulf takes a path that strive to preserve the gender civility relations as defined by David Hume (Hume, 1788) and would be the characteristic of the "French model" defined by the philosopher Philippe Raynaud: "the French trends of emancipation (organized or spontaneous) have had to define their own place and style within the quasi aristocratic backyard of the literary salons, the heroic mythology (until patriarchal for the communists) of revolutionary trends and the action of uniformization of the Republican state: from this rose maybe a particular ability that preserves the most precious element in the gender difference without abandoning the exigence of fairness and dignity" (Raynaud, 1989). 
This assumption was born out of observations from the field and discussions with lots of Arabian women claiming their emancipation while insisting in the difference between men and women and in their feminine values, often related to maternity, care and traits associated to delicacy, finesse, sense of planning and organization or other values that would be considered as sexists by the western feminists. The fact that these women, when they are single (that's a common case in the sample, 5 women out of 20 are married) are living in a situation where they have to supervise sometimes hundreds of people or deal with important budgets in their professional life while continuing living in their parents' home which is sometimes very traditional is as well a factor worth to explore to study the relation between the professional environment and the traditional values carried by the Arabian women in the Gulf.

Thus, the question asked at the end of the interview is "What kind of value do you think a woman can bring in her social environment?" with an optional reminder which is "what kind of thing a woman can bring more than a man in her professional environment?"

Definition of leadership, difficulties faced within the workplace as they are perceived and identified, the notion of achievement in a woman's life and specific values identified as could be carried by women allows, in a managerial perspective, to define the values that conduct to the emancipation of the Arabian women. They can also help pointing out their acceptance by the society, which is somehow proud of this, and finally, finding out the emergence of a new Arabian society in the Gulf where women are taking progressively their share in the economic power and impulse a new manner of management that seems well accepted and politically promoted.

To complete this brief literature review, let's glance at the few studies about the female managers in the Gulf. They are a bit outdated, such as the papers of Beverly Metcalfe (2006) or Katty Marmelout (2009) and highlight most of times the great difficulties to run qualitative interviews in good conditions with "ordinary" female managers (that was absolutely not the case during our study). Therefore, many studies had been conducted on female managers having reached very high and prestigious positions, often members of the local ruling elites and families. Those kind of examples cannot pretend being role models because their lifestyles and places within the local societies are too far away from the middle class, even the upper middle class. Those women are easy to reach and quite talkative, many colleagues and friends have given us some contacts in order to interview them but it appeared difficult to link them to the "real" society of the countries they are living in

Nevertheless, existing studies are stemming from cultural landmarks organizing relations between females and males that can be summarized by a certain number of elements. Thus, several studies about gender on employment market in the Middle East are highlighting the allocation of roles among genders shaped upon the following characteristics (Metcalfe, 2006, Marmenout, 2009):

1- Centrality of family better than the one of individual as key element of the society.

2- Recognition of the male as the only source of income for the household.

3- Values of modesty laying on dignity of the family as well as woman reputation.

4- A misbalance of powers within the private sphere formalized by the various family laws

Data found in researches such as "World Value Survey" are mentioning that Arabian countries tended to promote gender equality in the field of education but not in the access to the employment market (UNDP, 2003). The very recent change in the Gulf countries and particularly in Saudi Arabia is a strong message sent by the rulers and makes those papers outdated. The very strong focus on the religious factor as a key point in the multiple previous researches is as well a bias that is very common in the studies conducted by western non-resident searchers. That is the main reason that conducted us to run this longrange study. Concretely, from 2017 to 2020 , the job market became easier to access for females than for males, especially in Saudi because of the quota policy and the very strong incentives for companies to recruit female national staff.

However, according to the existing literature, this change does not comply with the local traditions ("urf" in Arabic language), that shows the need to protect women by creating a moral working environment. This idea is linked to the concept of Islamic law ("sharia' a") according to which a woman has to obey her husband (until a very recent period, this was the untangled base of all the human interactions in Saudi Arabia). Most of the existing research works were focused on factors linked to 
religion such as "qiwama", principle according to which a husband has to protect his wife and women have to preserve their modesty by covering themselves (Pipes, 2004). The paradigms of management in Muslim countries were defined almost only through those very religious oriented elements and some nonresident western searchers became specialists of this trend (Weir, 2000, 2003, 2004). Though, observations and findings collected from 2017 to 2020 as well as the interviews conducted are clearly showing that this framework, although it still exists, has been put aside by the rulers of the Gulf and firstly by the Saudi Crown Prince. It has become more symbolic and has been codified in the same way as the traditional family model or the prenuptial customs that are obviously remaining in the society, albeit in a far lighter form.

\section{FINDINGS AND DATA ANALYSIS: A CHARISMATIC AND TRANSFORMATIONAL LEADERSHIP}

Definitions of leadership given by the interviewees are really well matching with the "transformational leadership" as defined in the literature. This latter is itself an element of the "neocharismatic" approach of leadership (Allard-Poesi, 2012).

After coding the data, we found a vision of the leader as a "guide", a "father", a "mentor". According to F8, 37 years old, Saudi, the leader is "the one who knows the way and shows it to the others".

For F9, 49 years old from Bahrain, the leader "he has to have a view, something he can plan ahead, he can lead a team, has the personality and the charisma to convince the others of his point of view"

The leader is a role model as well for F16, 37 years old, Saudi: "Trying to be a good model for people to follow you and prepare the next person to be your follow-ship". In almost all the interviews, we found words and expressions describing a charismatic character, gifted with outstanding skills, that shows the way and guide the others to an objective that is bigger than themselves. According to those arguments, we are getting closer sometimes to the definition of the "charismatic legitimacy" from German sociologist Max Weber (Weber, 2014).

Most of the interviewed women are making a sharp distinction between the "leader" and the "manager". The leader is not considered mandatorily as someone that has some employees to supervise but someone with skills, innate gifts as F1, 28 years old Saudi says: "So not anyone can be a leader but of course some people are just leaders the way they are, they are born leaders as they say, but it's all about influencing, having good influence on others."

This conception of natural leadership, that conveys a supernatural and historic background, should be completely compliant with the Gulf society, which is, accordingly to the existing literature, supposed to be patriarchal and male oriented, and where females have to be protected by males. Though, most of the women interviewed are themselves managers and are most of times very proud and have a very flattering vision of their own role as supervisors (all of them are managing males). If they distinguish manager and leader, a vast majority of the interviewees are identifying themselves as leaders, and assume wearing the cape of "superhero" they have depicted when they have been asked on this.

The most nurturing interview concerning leadership is the one with F12, 28 years old Bahraini who changed her mind since our first meeting. One year after our first interview, the recorder worked this time and her situation had changed (she was promoted after her graduation). During our first appointment in 2018, F12 was like we have known her as a student in the MBA program: very self-confident and sure that she was herself a leader despite the slight gender discrimination encountered at workplace she was describing at that time. During the second interview, general conversation was more or less the same except when came the question on the definition of a leader when she adopted a more modest and realistic vision after having told us how her two new managers were sources of inspiration for her: "Not as they are [when asked if she was considering herself as a leader], but yes. To a certain extent, yes. I believe I do have the characteristics of being in the future on a wider scale, a leader."

This change of mindset can be explained by her recent promotion inside her company (that permitted her to discover management in a more concrete manner) and also by several business trips abroad where she had to represent her company (metallurgic industry) especially in the USA. One of the other factors of 
explanation is that her manager has changed and is now an alumnus of the MBA program she has just been graduate. During the first interview, she considered herself as a victim of the glass ceiling and gave many examples of discriminations she was encountering at work although she was estimating herself as a natural leader deserving to be promoted. One year after, like many other graduates of the MBA, she had been promoted at the expected position and her discourse had become smoother and more realistic vis à vis management and notion of leadership.

Among the younger interviewees, the idea according to which leadership can be acquired by experience while being a natural ability appears naturally. The idea that a leader was born from a particular situation where he reveals to himself and to the others his talents appears according to F15, 21 years old Bahraini when asked if she considers herself as a leader: "At the moment no, but hopefully with my industry, I can achieve it sooner or later, because right now I'm not beyond my comfort zone and I'm still in my bubble, so I'm looking forward to one day becoming a leader."

F13, 21 years old Saudi thinks as well that she is not yet ready when asked: "Not yet, I would love to be a leader. I'm still young, I need to be more strong, to be more open, I need to work with other people, other personalities"

Leadership is not only innate and charismatic according to the interviewees but the leader has also to be someone experimented to play his role of mentor. Meanwhile, the interviews are revealing as well expressions that seems to come straight from the literature of "personal development" with a lot of sentences such as "everyone can be a leader", that "everything is a matter of hard work and will" showing the strong influence of this kind of books and popular managerial literature that have spread within all the Gulf region for years

\section{Discrimination at Workplace}

A new dimension appears when data about difficulties due to gender faced at work by the interviewees are added to the coding process. It helps to better define the framework in which the values linked to world of work are being shaped in the minds of the females managers. First, it appears necessary to have a quick glance on the recent context, especially in Saudi Arabia, where the newly enacted regulations tend to make mandatory a certain share of Saudi women in every companies, including at managerial positions. At the moment the interviews have been conducted, the interviewees are thus evolving in a muting professional environment in which as trained and experimented women, they are considered as precious assets for the companies. Besides, several of them have recently been promoted or are on the verge to be promoted. Several recruitment agencies have specialized themselves in outsourcing and placement of Saudi nationals, particularly women.

This can be a valuable explanation of the results that clearly show that interviewed women are considering that discriminations may have been important in the past but that they are becoming rarer in the recent times. The other explanation of such a finding could be that the chosen sample for the study was mainly composed of women at managerial positions and seeking for promotions. Three students of the Royal University for Women in Bahrain have conducted a survey about gender discriminations at workplace mainly on under 30 years old non manager females working in the banking sector and the results lead them to conclude that the discriminations where, contrarily to our findings, very strong and were considered by those women such as a real glass ceiling. In this latter survey, the main factor explaining these discriminations for these women who had less than 3 years of work experience was the weight of cultural aspects and local tradition (Alabuainain, Al Bassam, Al Nuaimi, 2020). Due to the fact that this quantitative research haven't been conducted on more experimented women, it seems difficult to make other things that suppositions on this surprising result that doesn't really match with the data collected during our 3 years long study.

Nevertheless, this idea according to which it is difficult to be promoted while being a woman is not absent in the interviews I have conducted. F12, 38 years old Saudi, considers that one of the discriminations she has had to cope with was in the way to access managerial position, especially in her company, an oil and gas multinational, where she is working as a senior accountant. We can guess as well a slight feeling of frustration in F12's words: "So basically there were a lot who said "she is a female, 
she can't do that" and I hate it when someone says that. Just because I am a female, you think I can't go in the plant, and check out the process, or go on a business trip, or stay long hours? Or understand the terminologies and the in depth meaning of what aluminium manufacturing is? So there were a lot of people who were surprised $8 \mid P$ a g e when I got promoted from sales assistant to an administrator, and even more surprised when I got the MBA opportunity, like "what are you trying to achieve?"

The other interviewees do not mention personal cases of discriminations or issues they have had to face when they mention their own past, except through very ancient anecdotes or by mentioning some of their colleagues or relatives.

The link with the definition of leadership appears sharply in the words of several of them, particularly the Saudi ones when they evoke the guardian figure of Crown Prince Mohamed Bin Salman and its supposed role as a champion of women empowerment and job feminisation. He appears clearly as a model of charismatic leader who transforms the ones he is in charge of. F16, 38 years old Saudi drafted a direct link in her discourse between the Crown Prince decision to empower women and her company's decision (important oilfield contractor) to get her promoted at an executive position (she looks very proud to announce to me that she will be the second one to take such a position in this 5000 employees company).

However, the great majority of the interviewees are describing a very respectful and gender equity concerned professional universe where women have the same opportunities as males. Nevertheless, it is not difficult to spot a slightly stereotyped discourse on gender equality by analysing their interviews. Thus, F17, 37 years old Bahraini, head of sales in the aluminium industry had prepared the responses and read it to us on the screen of her laptop during the interview. Indeed, prior to the interview, she had asked about the main object of the questionnaire and in compliance to the methodology, it was answered to her that it was about women situation at their workplace in the Gulf. She had forecasted a prepared and stereotyped response presenting her company as a perfect one regarding this aspect and repeating several times that "everything is normal".

However, there is no particular reason to doubt on the words of a woman becoming head of sales of an industrial company at the age of 37 and who is constantly sent to business trips to represent her employer. This eagerness to prepare a precise written speech regarding this matter is somehow a bit curious, especially since this question has become a major regional stake, notably in Saudi Arabia.

In many companies of the region, it appears clearly that within the larger industries, a certain managerial protection exists towards women. It is not rare for posters promoting large prevention campaigns against gender discrimination, harassment or other type of offending behaviours to be visible everywhere in such companies. Such protecting environment finds its way in the narratives of the interviewed women who are often managers in such industries.

Nevertheless, the several females entrepreneurs interviewed or that have had to take some more traditional jobs or in smaller companies have different perceptions on gender discriminations faced at workplace. Thus F2, 29 years old Bahraini who has created a tea trading company is facing a situation where most of her competitors are males and where she has to conduct a real daily struggle in order to develop her business. She describes the launching of her company through the prism of gender and claims that most of the issues she is daily encountering are due to her gender: "I mean it was quite hard for me in the beginning, especially when I started I was young, I was like 24 or 25 .. sometimes I wasn't taken seriously, I have to say that. Because you know, I was a young girl and it was challenging. I mean I don't... I'm not sure if just because I'm a female or maybe it's just challenges that I faced. But I know my field specifically tea and trading all around the world is dominated by men. So it's quite difficult in different aspects. So in terms of how the clients would view you or the prospect... Or sometimes from my end towards the consumer like I know that a lot ... I had some hesitations to do business with certain countries, because I didn't feel... I was scared to do it because you know, I'm a woman. If I was a man ... but I don't like to put things in my mind. Like I personally don't but, I know it can be hard'.

Likewise, F11, 29 years old Bahrain from a renowned merchant's family in the oldest souk of the country describes the same kind of struggle. After a career begun in the banking sector, she is the general manager of a humanitarian NGO. While commenting her previous position in the finance sector, she 
describes an universe where women are spoiled: "in Bahrain I think, ever since I was born until now, I've been praised for being a women, rather than suppressed like other countries, and every time I've seen a woman in a managerial position they are very praised, and they're pushed to do more, and even at the bank, my three direct line managers, all three levels, were women."

However, when asked, during another conversation, why she did not work for the flourishing family business in the souk, she answers clearly that her brothers and father are in charge of it because souk is a matter of males. F11 checks in her narrative the assumption upon which despite the notable efforts of large companies and administrations to promote gender equality, discriminations, or rather gender assignation to specific roles remains strong as soon as the professional environment is less institutionalized. Therefore, for the small company created by F2 or in the family stores of F11's family, we remain standing in a traditional masculine universe that we could qualified as patriarchal.

\section{CONCLUSION AND RECOMMENDATIONS: A CULTURAL AND RELIGIOUS BACKGROUND?}

Crossing the data collecting concerning leadership and discrimination have thus a real interest. They are not especially correlated but they are completing each other. First, the vision of leadership is very charismatic according to the words of the interviewees: the leader transforms his environment, gives a strong vision, and creates a momentum toward an objective bigger than the individuals in charge of reaching it. The constant and repeated references to the strategic plans launched by the countries of the region (the most famous is the Saudi "Vision 2030" plan) illustrate very well the notion of "cause bigger than myself" and complies with the idea of a necessary charismatic leader to draft and run the plan.

Since the dominating idea in the society is the fact that a leader has to be strong, protecting and visionary, it appears nearly naturally that the women interviewed felt well in such a society that made their professional empowerment a priority. Even though the key indicators are showing that equality within the managerial positions is far from being reached, (only $8 \%$ of women are part of the top management in the banking sector in Bahrain for example), even though several interviewees highlight the difficulties faced to get promoted, they don't feel discriminated or do not express this feeling directly to the researcher as well as the assistant during less formal conversations organized in order to avoid bias linked to the searcher's position or gender.

The feeling and pride to be part of an avant-garde, to be themselves some enlighten leaders that shows the good examples appears therefore easily during the interviews. Our findings are therefore far away from the existing references in the literature review presented at the beginning of this paper. If the idea of protection of females by males appears in the discussions when we evoke the cultural and religious question or is underpinned during the conversation on management and professional environment, they are far from turning it into a key factor. Thus, values such as modesty, tradition of morality "urf", or guardianship of females by males "qiwama" that are linked to Islam and its weight in the local culture are far from being obvious as priorities in the women discourse.

The ground research, mixed to observations shows actually a kind of respect, courtesy, gallantry that could be qualified as "excessive" but which roots seem not really religious. Indeed, gender relations are very codified has we have observed it on several occasions, but the explanation is more cultural, linked to the Arabian tradition rather than directly linked to Islam or religious practice or custom. This major finding gives another grid of comprehension of the way to analyse the work relation between genders in the Gulf.

This new grid of understanding proves that promoting innovation and woman empowerment is completely possible but that the strategies have to adopt a few guidelines:

First, the promoters of innovation, especially related to fourth industrial revolution, have to take into consideration the cultural tradition more than religious issues when implementing gender policies in the Gulf.

Second, the empowerment of women has to be guided by a strong vision according to their vision of leadership. Trying to implement alternative models is possible, but not too suddenly. Visions and methods 
taken from western consultants are most of time dealing with "participation", "governance" and other western oriented concepts whereas the local vision of leadership is matching with neo-charismatic definition and it seems that there is not any special request for another style. Implementing policies encouraging innovation is useless without sticking to the wills of existing female managers.

Third, fighting against gender discrimination cannot imitate the western way. Female managers are most of times feeling comfortable with this and the public administration as well as the largest companies seem to have implemented strong policies regarding this issue. Concerning gender discrimination at workplace, feelings are important. Although statistics are proving that the male/female repartition is far from equality and that women do not have really equal opportunity to be promoted in the Gulf countries, the fact that they do not consider themselves as discriminated is to be taken into consideration.

To better promote innovation, especially to adapt the working environment and to prepare female manager to be fully part of the fourth industrial revolution, it appears necessary to create a Gulf adapted woman empowerment model that takes into consideration the feelings and views of the concerned public before implementing "ready to use" policies.

Additionally to this study, the policy makers could investigate on the "values" carried by female managers at workplace and their vision of what is the main achievement in a woman's life in order to launch more adapted and precise empowerment dispositive based on other things than just raw numbers and statistics. That is mainly what we have done in another part of our long-range study that has been published in French language.

\section{REFERENCES}

Allard-Poesi, F. (2012). Management d'équipe. Dunod.

Avolio, B., Walumbwa, F., \& Weber, T. (2009). Leadership: current theories, research and future dimensions. Annual Review of Psychology, 60, 421-449.

Bass, B. (1985). Model of transformational leadership. In T. Mech \& G. McCabe, G (Eds.), Leadership and academic librarians (pp. 66-82). Westport.

Becker, H. (2014). Des vies ordinaires. Lectures. Les notes critiques.

Burns, J.M. (1978). Leadership. Harper \& Row.

DeVault, M. (1999). Liberating Methods: Feminism and Social Research. Temple University Press.

Forsyth, D. (1998). Group Dynamics. Belmont, CA, Wadsworth Publishing Company.

Hume, D. (1972). Essais politiques, trad. 1788, Vrin, 223-281.

House, R., Javidan, M., Hanges, P., \& Dorfman, P. (2002). Understanding Cultures and Implicit Leadership Theories Across the Globe: An Introduction to Project GLOBE. Journal of World Business, 37, 3-10.

Howell, J., \& Shamir, B. (2005). The Role of Followers in the Charismatic Leadership Process:

Relationships and Their Consequences. The Academy of Management Review, 30(1), 96-112.

Judge, T.A., \& Piccolo, R. (2004). Transformational and Transactional Leadership: A Meta-Analytic Test of Their Relative Validity. Journal of Applied Psychology, 89(5), 755-768.

Lacheret, A. (2020). La femme est l'avenir du Golfe. Le Bord de l'Eau.

Marmenout, K. (2009). Women-Focused Leadership Development in the Middle East: Generating Local Knowledge. INSEAD Working Paper No. 2009/25/IGLC.

Metcalfe, B.D. (2006). Exploring Cultural Dimensions of Gender and Management in the Middle East. Thunderbird International Business Review, 48(1), 93-107.

Pipes, D. (2004). Miniatures. Routledge.

Raynaud, P. (1989). Les femmes et la civilité : aristocratie et passions révolutionnaires. Le Débat, 57(5), 161-166.

Rosanvallon, P. (2014). Le Parlement des invisibles. Seuil, Raconter la vie.

Tariq, M., \& Syed, J. (2017). Intersectionality at Work: South Asian Muslim Women's Experiences of Employment and Leadership in the United Kingdom. Sex Roles, 77, 510-522. 
Van Seters, D., \& Field, R. (1990). The evolution of leadership theory. Journal of Organizational Change Management, 3, 29-45.

Weber, M. (2014). La domination. La Découverte.

Winkler, I. (2009). Contemporary leadership theories. Springer.

72 Journal of Strategic Innovation and Sustainability Vol. 15(5) 2020 